\title{
The Importance of Stakeholders Approach in Public Policy Making
}

\author{
Marlan Hutahaean \\ lecturer at department of public administration \\ faculty of social and political sciences, university of HKBP nommensen \\ Medan-North Sumatra, Indonesia \\ marlanhutahaean1965@gmail.com
}

\begin{abstract}
This article wants to explain athe importance of stakeholders approach in local regulations making. By using qualitative method and secondary data, this research found that the stakeholders, particularly those affected with local regulation will not be involved. Local regulation is more likely to be monopolized by government officials and local parliament. Based on these findings, policy recommendation that should be done is the need to apply the stakeholders approach in each local regulation in the future

Keywords: the technocratic level, political level, the public interest.
\end{abstract}

\section{INTRODUCTION}

This paper wants to explain the importance of implementing the stakeholders approach in public policy, particularly local regulations (Peraturan Daerah). The focus is the application of stakeholder analysis on local regulations making on the environment. Assumptions proposed was formulated during the policy-making, particularly in the form of local regulations, stakeholders approach is less applied as a whole. If anything is done, it is still limited to certain circles. Based on these assumptions, there is a tendency that the rulemaking areas are less likely to provide great benefits to the target group.

Stakeholders approach have progressed through a series of recognisable phases: from awareness raising in the late 1960s (the antimodernisation critique of the transfer of technology paradigm [1]. Its popularity has increased with the seminal publication of Freeman's [2]. Strategic Management: A Stakeholder Approach. Stakeholders approach has received extensive examination, with it being suggested that there are over 100 articles and several texts examining [2]. Much of this literature has suggested that Stakeholders approach allows the organization to consider a wider range of influencers when developing strategy and that earlier theories of the firm do not consider all of the "groups" that influence organizational activities.

The term "stakeholder" as a label for any actor - institution, group or individual - with an interest or a role to play in the societal decisionmaking process. Different stakeholders may have different interests. Engagement strategies should thus be adjusted to context: differing needs, programme phases, formal requirements, as well as national process and national and local culture [4].

The analysis of stakeholders approach is urgent, so that public policies such as local regulations which generated from is more qualified. In the case of environmental policy, for example, there is a failure of implementation because the lack of stakeholders approach acceptance [5]. Environmental problems are typically complex, uncertain, multi-scale and affect multiple actors and agencies. This demands transparent decisionmaking that is flexible to changing circumstances, and embraces a diversity of knowledges and values. To achieve this, stakeholder participation is increasingly being sought and embedded into environmental decision-making processes, from local to international scales [6]. Some experts had previously conducted a study on the connection between stakeholders approach and environmental issues [7].

During this time, a lot of resulting policies does not meet the qualifications to be expected, or if 
it can be called a poor quality. Data for the policy in the form of local regulations, shows that since 2002 to 2011 , from about 13,000 , there were 4,000 pieces that were rejected by the central government as opposed to the Law No. 10 Year of 2004 concerning the Establishment Regulation Legislation. Some local regulations are rejected because they do not accommodate the interests of the community. Correspondingly, the latest data shows that there are approximately 42,000 local regulations are problematic because they hinder developments. Based on the above, the research question is how does to apply the stakeholders approach in formulating local regulation relating to the environment?

\section{METHOD}

This study uses a qualitative method. The data used to explain this recent research is the primary and secondary data. Primary data was collected through in-depth interviews to those who were closely with environmental issues, such as the environmental agency of North Sumatra province, North Sumatra spacecraft environment, and environmental experts. Secondary data was collected from existing documents such as books, research results, journals, articles, print and electronic media or website relating to the research theme.

The data collected in this study, then be analyzed with descriptive analysis. By this technique it will be illustrated throughout the data or facts obtained from the field by applying the following procedure: (a) Using descriptive analysis to develop categories that are relevant to the purpose of research. (b) Interpretation of the results of descriptive analysis is done by referring to the data and theories accordingly.

\section{RESULTS AND DISCUSSIONS}

\section{A. Facts on Environmental Policy}

Various national policies have actually regulated how protecting the environment such as the Law No. 23 Year of 1997 on Environmental Management. Then, Law No. 41 Year of 1999 on Forestry. Lastly, the rules concerning the environment is regulated by Law No. 32 Year of 2009 on the Protection and Environmental
Management. The problem is that it often fails to policy implementation.

In 2008 data shows that for nearly 50 years, Indonesia forest loss $40 \%$ of the total forest estate. Previously, between the years 2000-2005, about 1.8 million hectares of Indonesia's forests damaged. On the other hand, in Book Reports Indonesia Country, Reports on Need for Reform and Governance Capacities in Asia page number 62, shows that environmental policies are not effective or fail to prevent and protect the sustainability of natural resources and environmental quality. On a scale of 1-10 option from worst to best, Indonesia is located on the second level.

In addition, the Environmental Performance Index (EPI), is always used as the basis for measuring the performance of the environmental management in the world. EPI ranking will indicate how much government attention to environmental issues in the two policy areas: (1) protect human health from various hazards, and (2) to protect the ecosystem. Of the two objectives of the policy, formulate EPI issues 9 and 20 indicators. In 2014, the top five countries that recaptures the highest ranking EPI is Switzerland, Luxemburg, Australia, Singapore and the Czech Republic. While Indonesia, is ranked 112 with an index of 44.36 out of 178 countries.

The main cause of poor achievement of Indonesian environmental management, which of course including the regions, is deforestation and forest degradation (Reducing Emissions from Deforestation and forest Degradation (REDD)). Today, a variety of forest destruction through deforestation is still underway. No exception, and even then the incident took place in the provincial areas, such as Riau, South Sumatra, North Sumatra, East Kalimantan, South Kalimantan, and others. Several Non-Governmental Organization (NGO) such as the Environmental Forum (WALHI) in various provinces, constantly remind national and local governments in order to preserve the forest. Not only that, countries that produce pollution also world finance even countries such as Indonesia's tropical forest conservation. Norway, one of the countries in Europe is very concerned with the preservation of forests through REDD and REDD + program, which bases its implementation on the 
areas of Borneo. Another problem associated with environmental destruction is the vulnerability of natural disasters, loss of biodiversity and ecosystems, and climate change. Furthermore, of course, the impact of environmental destruction is the poverty, sustain economic development, and health problems.

In addition to the destruction of forests, environmental problems can be caused by high levels of pollution. Air pollution, especially for urban communities is certainly a very big problem. The transport sector was the sector most contributing significantly to poor urban air. The transportation sector accounts for about $80 \%$ of the air pollution, which is then followed by the emissions from industry, forest fires, and domestic activities.

Based on the above facts and data, the stakeholders in the Environment Agency in every province or district / city, must be courageous and able to implement environmental policies as established by Law No. 32 Year of 2009. This form of implementation is meant to review, revise and / or file a draft of local regulations (Rancangan Peraturan Daerah) on the prevention of environmental degradation. Various draft of local regulation referred to as the destruction of forests (deforestation), draft of local regulation of Timber Utilization Locale, which aimed to reduce the circulation of illegal timber in one province, draft of local regulation of green open space, draft of local regulation of Building Permit that Environmental, draft of local regulation about Watershed, draft of local regulation about thresholds of Vehicle Exhaust, and so on. Actions against illegal logging is also a homework from the Environment Agency Provinces throughout Indonesia. It is said that, illegal logging is a major cause of forest destruction or the environment.

\section{B. Using Stakeholders Analysis Approach in Environmental Policy Formulation}

As previously mentioned, this paper will describe the use of stakeholder analysis approach in policy-making environment. Stakeholders are any party, individual or group that can be linked to or influenced on the policy. Stakeholders are any party having an interest in the policy.
A stakeholder analysis is a tool to analyze the various actors and interests in an issue of public policy. Stakeholders will influence and be influenced policies in different stages. The conventional democratic theory states that when a person is already included in the election, then the right, in policy formulation has been handed over to the representatives in parliament. On the theory of modern democracy, the rights of citizens are not left entirely to his deputy, because citizens have the right to actively participate in politics to influence policy. A stakeholder analysis examines the interest of stakeholders in relation to the policy and understand which stakeholders will be most influential. This analysis is useful in prioritizing their interactions with the major interest groups, especially those directly affected. To perform the analysis of interest can be used a method that classifies Power Grid stakeholders in accordance with the level of interest, respectively, as shown in Figure 1 [8].

Figure 1. Power/Interest Grid

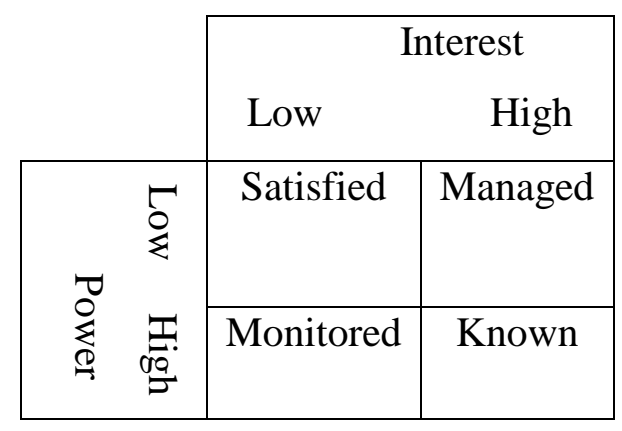

Source: Pramusinto's RIA Training Materials Exposure, 2012.

Stakeholders who have great interest but little power, need to be managed, one time, when you move it will be the basis of strength and capable of lobbying. Those who have great power, but low interest, should be maintained so satisfied, they need to be a patron or supporter of the policy. Power/interest grid analysis provides information of most cooperative stakeholders, influential, engaged and the ones who only receive information, in addition to information about people who may be difficult to achieve, challenging and difficult to engage. 
In understanding the importance and influence of the legitimate stakeholders should be kept every risk groups that need special attention. It should be noted and taken into account: who will be adversely affected by the policy? Is there one of the stakeholders that there is a vulnerable community members? Are there any vulnerable groups who are very difficult to engage due to geographical problems, do not have a voice or are not visible? Will any vulnerable groups require special attention and assistance during a stakeholder engagement processes?

Because of the many stakeholders involved in any decision-making, then among stakeholders must have the principles of a relationship. The principles of these relationship are, first, transparency or disclosure of information. This principle contains, among others, (a) The Government of province or regency/city, should provide relevant material information in a way that is easily accessible and understood by stakeholders; (b) Information is not gossip or slander; and (c) Information should essentially be trusted. Example; how much the level of pollution? How many suffered by the community due to the smog? How many people suffered from effects of bad policy? Second, accountability/responsibility work in a transparent manner. This principle contains, among others, (a) The Government of province or regency/city, must be properly managed, scalable, and according to the organization's internal interests while taking into account the interests of stakeholders, (b) For the purposes of the Government whom the provincial or district/city work for? If the public interest, who the public is? The task of the provincial or district/city is keeping all interests fairly. Third, responsibility. Some of the elements contained in these principles, among others, (a) the Company relating to the environment must comply with laws and regulations and implementing responsibility towards society and the environment; and (b) The responsibility of internal bureaucracy must not conflict with external responsibilities. Fourth, Independence. On this principle, there is no conflict of interest. Government agencies should be managed professionally without any conflict of interest and influenced or pressured from any party. The goal is that in the decision no pressure or influence from any party, and consequently the decisions taken can be objective Fifth, Fairness, namely equality and fairness. On this principle, there is a fair treatment and equal stakeholders in fulfilling the rights arising under the agreement or the applicable legislation

However, various obstacles in the analysis of stakeholders must be met. Many of these challenges include (1) Choosing the right stakeholders related to policy issues or problems to be formulated; (2) Finding the right way to choose to have no representation; (3) Finding the right way to avoid the situation that the stakeholder engagement process is not dominated by groups or individuals; (4) Looking for a way that stakeholders do not make the process of formulation and regulatory assessment rambling; and (5) Looking for ways on how to position the stakeholders in the decision-making process, voting rights or rights just talk.

\section{CONCLUSION}

The problem at this time is the wrong approach in formulating the regional regulations. The most happen are that local regulations only compiled and discussed the policy elite, such as the government and legislature members only. Communities as stakeholders who will be the target group are very rarely involved in drafting local regulations.

There is an assumption that public participation is already represented by a board member. Yet although board members are representatives of the people, but the mandate remain in the hands of the people. That is, any discussion of policy issues were then addressed through a policy instrument, appropriately involving the community. This condition resulted in many local regulations that ultimately problematic. Problematic local regulations is certainly vulnerable to cancellation by the central government. If that happens, it will be futile amount of costs incurred in making local regulations as mentioned earlier.

\section{ACKNOWLEDGMENTS}

The Author would like to thank to the Public Administration Department, Faculty of Social and Political Sciences, Nommensen HKBP University 
that has funded this research. Thanks are also delivered to the Indonesian Environmental Forum of North Sumatra and the Environment Agency of North Sumatera Province has provided data and related information for this research.

\section{REFERENCES}

[1] Reed, M.S., "Stakeholder participation for environmental management: A literature review," Biological Conservation, vol. 141, pp. 2417-2431, 2008.

[2] Freeman, Strategic Management: A Stakeholder Approach. MA: Pitman Publishing Company, 1984.

[3] Donaldson, T. and Preston, L.E., "The stakeholder theory of corporation: concepts, evidence, implications", Academy of Management Review, Vol. 20 No. 1, pp. 65117, 1995.

[4] OECD, Stakeholder Involvement in Decision Making: A Short Guide to Issues, Approaches and Resources, 2015.

[5] Gregory, Robin, and Wellman, Katharine, "Bringing stakeholder values into environmental policy choices: a communitybased estuary case study," Ecological Economics, vol. 39, pp. 37-52, 2001.

[6] Stringer, L.C., Reed, M.S., Dougill, A.J., Rokitzki, M., Seely, M., "Enhancing participation in the implementation of the United Nations Convention to Combat Desertification," Natural Resources Forum, vol. 31, pp. 198-211, 2007.

[7] Toffel, M.W., and Delmas, Magali, "Stakeholders and Environmental Management Practices: An Institutional Framework," Business Strategy and the Environment, vol. 13, pp. 209-222, 2004.

[8] Education and Training Team, The Modul of Education and Training of Regulatory Impact Analysis.Yogyakarta: MPA-Faculty of Social and Political Sciences-UGM, 2012. 